\title{
ROLA OPIEKI PIELĘGNIARSKIEJ W ZAPOBIEGANIU POWIKŁANIOM SERCOWO-NACZYNIOWYM U CHORYCH KWALIFIKOWANYCH DO ENDOPROTEZOPLASTYKI STAWU BIODROWEGO
}

\section{THE ROLE OF NURSING CARE IN THE PREVENTION OF CARDIOVASCULAR COMPLICATIONS IN PATIENTS REFERRED FOR HIP REPLACEMENT}

\author{
Katarzyna Majka ${ }^{1,2}$, Andrzej Krupienicz ${ }^{2}$, Robert Olszewski ${ }^{3}$ \\ ${ }^{1}$ Klinika Traumatologii i Ortopedii \\ Wojskowy Instytut Medyczny, Warszawa \\ ${ }^{2}$ Zakład Podstaw Pielęgniarstwa \\ Warszawski Uniwersytet Medyczny
}

DOI: https://doi.org/10.20883/pielpol.2017.40

\begin{abstract}
STRESZCZENIE
Choroba zwyrodnieniowa stawu biodrowego jest chorobą cywilizacyjną. Cierpi na nią w Polsce około $8 \mathrm{mln}$ osób. Praktyka kliniczna wykazała, że opieka pielęgniarska w okresie okołooperacyjnym jest tak samo ważna jak wybór rodzaju protezy oraz wpływa na jej trwałość.

Dane pochodzące z USA pokazują, że liczba osób w wieku powyżej 65 roku życia wzrośnie z 25 do 30\% populacji w ciągu najbliższych 30 lat. Większość operacji ortopedycznych i zabiegi naczyniowe wykonywane są w tym wieku. Operacje stawu biodrowego są kwalifikowane jako pośrednie ryzyko okołooperacyjnych zgonów i powikłań sercowo-naczyniowych. Szczególną uwagę należy zwrócić na kwalifikacje pacjentów obciążonych chorobami sercowo-naczyniowymi do endoprotezoplastyki stawu biodrowego.

Cel. Celem pracy jest ukazanie roli opieki pielęgniarskiej zarówno w okresie przedoperacyjnym, jak i pooperacyjnym u chorych kwalifikowanych do endoprotezoplastyki stawu biodrowego.
\end{abstract}

SŁOWA KLUCZOWE: opieka przedoperacyjna i pooperacyjna, endoproteza stawu biodrowego, powikłania sercowo-naczyniowe.

\section{Endoprotezoplastyka stawu biodrowego}

Choroba zwyrodnieniowa stawu biodrowego to choroba polegająca na przedwczesnym zużyciu i zwyrodnieniu tkanek tworzących staw biodrowy. WHO i ONZ ogłosiła lata 2000-2010 dekadą kości i stawów. Choroba zwyrodnieniowa stawu biodrowego została zakwalifikowana do grupy społecznych chorób narządu ruchu ze względu na częstość występowania w społeczeństwie [16]. Występuje zazwyczaj u osób starszych po 60 roku życia, chociaż może rozpocząć się także u osób młodych, w wieku 35-40 lat [17]. Zmiany cho-

\begin{abstract}
Introduction. Osteoarthritis is a civilization disease. About 8 million people suffer from osteoartthritis in Poland. Clinical practice has shown that perioperative nursing care is just as important as the choice of the prosthesis and its durability. US data show that the number of people over 65 will grow from 25 to $30 \%$ of the population over the next 30 years. Most orthopedic surgery and vascular surgery are performed at this age. Hip surgery is classified as an indirect risk for perioperative mortality and cardiovascular complications. Particular attention should be paid to the qualification of patients with cardiovascular disease for hip arthroplasty. Aim. The aim of the study is to show the role of nursing care both in the preoperative and postoperative period in patients qualified for hip replacement.
\end{abstract}

KEYWORDS: preoperative and postoperative care, hip joint endoprosthesis, cardiovascular complications.

robowe można podzielić na pierwotne (o niejasnej etiologii) i wtórne (rozwijają się w następstwie zmian wrodzonych, urazowych, zapalnych, nowotworowych, hormonalnych oraz zaburzeń metabolicznych). O wyborze leczenia decyduje przede wszystkim stan ogólny pacjenta (wiek, płeć, wydolność krążeniowo-oddechowa), a także zaawansowanie i postać kliniczna choroby [2]. Alloplastykę stawu biodrowego wykonuje się w trybie planowym, poddając uprzednio pacjenta szeregowi badań (badania radiologiczne, laboratoryjne i inne na zlecenie lekarza prowadzącego). Wybór odpowiedniej 
protezy dla pacjenta jest jedną z podstawowych rzeczy w planowaniu zabiegu operacyjnego przez operatora. Prawidłowy dobór implantu ma ogromny wpływ na wytrzymałość sztucznego stawu [17].

\section{Kwalifikacja pacjentów z chorobami serca do niekardiologicznych zabiegów chirurgicznych}

Ocena ryzyka powikłań sercowo-naczyniowych u chorych poddawanych niekardiologicznym zabiegom chirurgicznym jest coraz ważniejszym problemem klinicznym. Wynika to z faktu starzenia się społeczeństwa, obciążenia chorobami układu krążenia oraz wzrostu występowania schorzeń niekardiologicznych. Wspólna Grupa Robocza Europejskiego Towarzystwa Kardiologicznego (ESC) i Europejskiego Towarzystwa Anestezjologicznego (ESA) do spraw oceny ryzyka sercowo-naczyniowego i postępowania u pacjentów poddawanych operacjom niekardiochirurgicznym uznała zabiegi ortopedyczne - endoprotezoplastykę stawu biodrowego jako średnie ryzyko (1-5\%) wystąpienia powikłań sercowo-naczyniowych [5]. Przy ocenie ryzyka wystąpienia powikłań kardiologicznych u chorego w okresie okołooperacyjnym i pooperacyjnym należy wziąć pod uwagę:

1. występowanie choroby sercowo-naczyniowej (stopień zaawansowania):

- chorobę niedokrwienną serca [8].

- niewydolność serca [9].

- nadciśnienie tętnicze [10].

- wady zastawkowe serca $[11,12,13]$.

- zaburzenia rytmu i przewodzenia [14, 15]

2. współistniejące choroby (cukrzycę, niewydolność nerek, zaburzenia hematologiczne, przewlekłe schorzenie układu oddechowego)

3. wykonanie dodatkowych badań oceniających układ krążenia (np.: USG Doppler, koronarografii) $[6,7]$.

Bardzo przydatny w pracy zarówno chirurga, jak i pielęgniarki jest arkusz oceny ryzyka powikłań kardiologicznych przed operacją chirurgiczną. Arkusz ma w sposób ilościowy pomóc w wyodrębnieniu pacjentów z grupy wysokiego ryzyka [6].

\section{Przedoperacyjna opieka pielęgniarska}

Nowoczesne pielęgniarstwo kojarzy się z pojęciami: proces pielęgnowania, modele opieki pielęgniarskiej, holizm - jakość opieki pielęgniarskiej, standardy, procedury pielęgniarskie i algorytmy postępowania pielęgniarskiego. Holistyczna opieka nad pacjentem składa się z opieki przedoperacyjnej, okołooperacyjnej i pooperacyjnej.

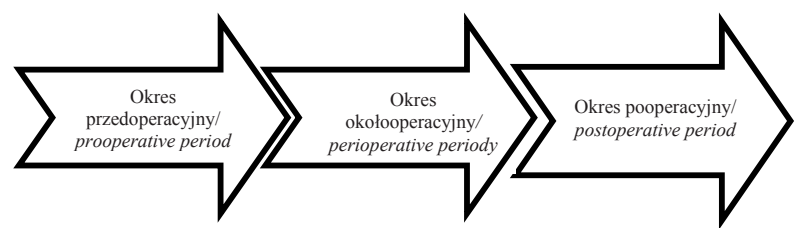

Rycina 1. Schemat opieki pielęgniarskiej Figure 1. Scheme of nursing care

Źródło: opracowanie własne

Source: author's own analysis

Nie da się określić tylko pooperacyjnej opieki pielęgniarskiej, gdyż ściśle wiąże się ona z opieką przedoperacyjną i okołooperacyjną. Dobrze zebrany wywiad owocuje postawieniem odpowiedniej diagnozy i wykonaniem właściwej procedury pielęgniarskiej. Ukierunkowane i specjalistyczne przygotowanie zawodowe upoważnia pielęgniarkę do realizowania planu opieki pielęgniarskiej nad pacjentem po endoprotezoplastyce stawu biodrowego. Określenie roli pielęgniarki w opiece nad pacjentem stanowi kluczowe zagadnienie wyznaczające zakres kompetencji, obowiązków i funkcji pełnionych przez pielęgniarkę. Staje się ona w procesie diagnostyczno-leczniczym członkiem zespołu interdyscyplinarnego. Jest łącznikiem pomiędzy lekarzem a pacjentem [18].

\section{Pielęgniarska ocena stanu chorego}

Okres przedoperacyjny to dla pielęgniarki moment wzajemnego poznania się z pacjentem. Chory w nowym środowisku musi poczuć się bezpiecznie i pewnie, aby oddać się pod opiekę zespołowi terapeutycznemu. Ocena stanu bio-psycho-społecznego pacjenta to w wywiadzie pielęgniarskim zwrócenie uwagi na ewentualne nieprawidłowości dotyczące wszystkich układów.

Tabela 1. Pielęgniarska ocena stanu pacjenta Table 1. Nursing assessment of a patient

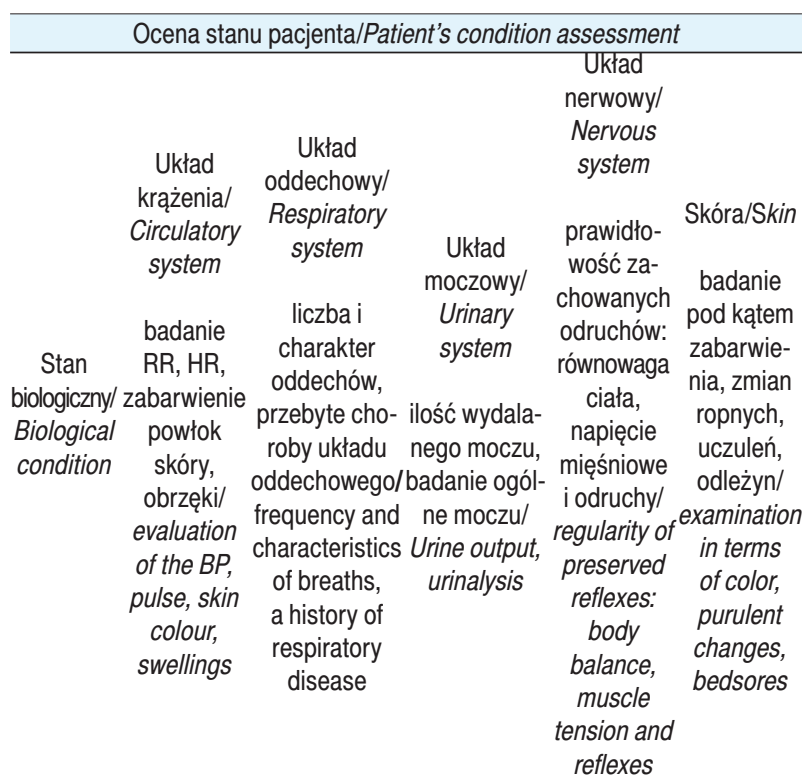




\begin{tabular}{|c|c|c|}
\hline $\begin{array}{c}\text { Stan } \\
\text { psychiczny/ } \\
\text { Psychical } \\
\text { condition }\end{array}$ & $\begin{array}{l}\text { Nastawienie } \\
\text { pacjenta do pacjenta do } \\
\text { choroby/ leczenia/ } \\
\text { Patient's at- Patient's } \\
\text { titude to the attitude to } \\
\text { disease. } \\
\end{array}$ & $\begin{array}{c}\text { Relacje } \\
\text { chorego } \\
\text { Relacje cho- z persone- } \\
\text { rego z innymi lem medycz- } \\
\text { pacjentami/ nym/ } \\
\text { Relations with Patient's re- } \\
\text { other patients. lations with } \\
\text { the medical } \\
\text { staff. }\end{array}$ \\
\hline $\begin{array}{l}\text { Stan } \\
\text { społeczny/ } \\
\text { Social } \\
\text { condition }\end{array}$ & $\begin{array}{l}\text { Warunki Ocena sytuacji } \\
\text { materialno- rodzinnej } \\
\text { / -bytowe/ pacjenta/ } \\
\text { Patient's Assessment } \\
\text { living condi- of the patient's } \\
\text { tions. family status. }\end{array}$ & 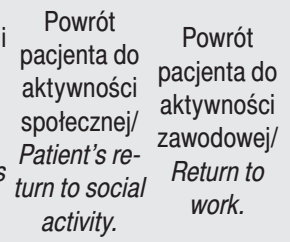 \\
\hline
\end{tabular}

Źródło [19, 20]

Source $[19,20]$

\section{Edukacja przedoperacyjna pacjenta}

Przedoperacyjna edukacja pacjenta to rozmowa na tematy dotyczące przebiegu operacji, procesu pielęgnowania i rehabilitacji po okresie okołooperacyjnym. $Z$ pacjentem przed zabiegiem operacyjnym rozmawia zarówno lekarz, jak i pielęgniarka. Lekarz rozmawia z pacjentem, wyjaśniając krok po kroku przebieg operacji. Pielęgniarka powinna jasno przedstawić to, czego pacjent może spodziewać się po operacji. Im bardziej pacjent jest zorientowany, tym łatwiej będzie mu się dostosować do późniejszych wymagań pielęgniarki. Należy uświadomić pacjenta na temat korzyści płynących z prawidłowo wykonywanych ćwiczeń oraz jakie czynności musi ograniczyć funkcjonując ze sztucznym stawem. Edukacja pacjenta dotyczy także powikłań ze strony wszystkich układów. Szczególną uwagę należy zwrócić na powikłania ze strony układu krążenia: zakrzepicę żylną, obniżenie lub podwyższenie tętna, podwyższone ciśnienie. Ważne są również powikłania ze strony układu oddechowego: niedodma, zapalenie płuc. Pielęgniarka uczy pacjenta wykonywania izometrycznych skurczów mięśni łydki i stopy, aby uniknąć wystąpienia zakrzepicy żylnej. Jest ona pośrednikiem pomiędzy pacjentem a rehabilitantem. Oprócz ćwiczeń w dobie poprzedzającej operację pielęgniarka podaje na zlecenie lekarskie antykoagulanty jako profilaktykę zakrzepowo-zatorową. W celu niedopuszczenia do powstania powikłań ze strony układu oddechowego pielęgniarka zachęca pacjenta do gimnastyki oddechowej. Oklepywanie pacjenta ma na celu odrywanie wydzieliny, a wysokie ułożenie ułatwia oddychanie [21].

\section{Diagnostyka przedoperacyjna}

Diagnostyka przedoperacyjna pacjenta na oddziale ortopedii to przygotowanie chorego i wykonanie przez pielęgniarkę zleconych przez lekarza badań. Zaliczamy do nich badania obrazowe: tomografię komputerową, rezonans magnetyczny, ultrasonografię (USG), badania rentgenowskie; badania laboratoryjne: morfologię, biochemię, układ krzepnięcia, grupę krwi i czynnik Rh oraz: EKG, pomiar wzrostu, masy ciała, pomiar tętna, ciśnienia, oddechu i oznaczenie poziomu glukozy. W zależności od różnych współistniejących jednostek chorobowych u danego pacjenta po konsultacji z lekarzem kardiologiem lub internistą wykonuje się dodatkowe badania [19].

\section{Okres okołooperacyjny}

Pomyślny wynik endoprotezoplastyki stawu biodrowego zależy od prawidłowego przebiegu okresu okołooperacyjnego i pooperacyjnego. Okres okołooperacyjny podzielony został na 3 części: przygotowanie pacjenta do operacji, operację i znieczulenie oraz czas, w którym pacjent powraca do normalnego funkcjonowania. Lęk związany ze znieczuleniem i zabiegiem operacyjnym odczuwa wielu pacjentów. Przyczyną lęku jest przede wszystkim ból towarzyszący po operacji oraz ryzyko powikłań okołooperacyjnych, ze śmiercią włącznie.

Czynniki, które mogą zwiększać niebezpieczeństwo powikłań w trakcie znieczulenia u pacjentów kwalifikowanych do endoprotezoplastyki stawu biodrowego po 65 roku życia, to występowanie: cukrzycy, RZS, niewydolności nerek, POCHP, wad zastawek serca, niedokrwistości, żylnej choroby zakrzepowo-zatorowej, psychozy, choroby nowotworowej, nadużywania alkoholu i depresji [22-25]. Anestezjolog w ramach premedykacji na 30-60 min przed zabiegiem operacyjnym podaje najczęściej benzodwuazepiny, opioidy i niesteroidowe środki przeciwzapalne. Działanie tych leków może być wydłużone ze względu na zmianę farmakokinetyki i farmakodynamiki związanej z wiekiem, np. czas półtrwania midazolamu u ludzi po 65 roku życia wydłuża się do 8,5 godziny, podczas gdy u ludzi poniżej 40 roku życia wynosi 4 godziny [26].

Wybór znieczulenia zależy od lokalizacji i rodzaju choroby, rodzaju i rozległości zabiegu operacyjnego, stanu ogólnego pacjenta i chorób współistniejących, sprawności zespołu operującego, umiejętności i możliwości anestezjologicznych. Niezależnie od wyboru metody znieczulenia, które zapewniłyby: odpowiednie warunki chirurgiczne, odpowiednią analgezję i amnezję, minimalne uboczne skutki dla układu krążenia i oddychania, poprzez przetrwanie częściowej analgezji na okres pooperacyjny, musimy być wyczuleni na występowanie objawów ubocznych, takich jak nudności, wymioty i zawroty głowy i powiązanie ich ze znieczuleniem. W okresie bezpośrednio po operacji należy pamiętać o prawidłowym wypełnieniu łożyska naczyniowego przez przetoczenie odpowiedniej ilości płynów. Podaż 
płynów ma zabezpieczyć podstawowe zapotrzebowanie i uzupełnić straty śródoperacyjne [27]. Znieczulenie pacjentów w podeszłym wieku nakłada na zespół anestezjologiczny obowiązek właściwego nadzoru śródoperacyjnego. Warunkiem bezpiecznego znieczulenia jest obecność przez cały czas trwania zabiegu zespołu anestezjologicznego (lekarza i pielęgniarki) oraz właściwe przygotowanie stanowiska znieczulania. Anestezjolog wraz z pielęgniarką nadzoruje pacjenta w trakcie operacji, podtrzymuje znieczulenie poprzez podawanie kolejnych dawek leków oraz zapobiega lub leczy stany mogące doprowadzić do zagrożenia życia lub zdrowia pacjenta.

Pacjenci leczeni chirurgicznie mogą wymagać ułożenia na plecach (standardowa pozycja na plecach, pozycja litotomijna, Trendelenburga), boku lub brzuchu. Stwarza to szereg problemów anestezjologicznych, szczególnie u pacjentów w podeszłym wieku i otyłych, z chorobami układów: krążenia i oddechowego [28, 29].

Koniec operacji nie jest końcem pracy dla zespołu anestezjologicznego. Jeżeli pacjent był znieczulany ogólnie, należy go wybudzić i przekazać na oddział pooperacyjny (POP). W większych szpitalach na oddziałach pooperacyjnych dyżuruje na stałe anestezjolog i pielęgniarka, w mniejszych szpitalach pacjentami z oddziału pooperacyjnego opiekuje się zespół anestezjologiczny znieczulający na pobliskim bloku operacyjnym. Zadaniem anestezjologa i pielęgniarki w okresie pooperacyjnym jest głównie leczenie bólu i zapobieganie powikłaniom, do jakich może dojść w okresie pooperacyjnym, np. depresji oddechowej [30].

\section{Okres pooperacyjny}

Po zabiegu operacyjnym pacjent przekazywany jest na salę pooperacyjną, gdzie jest monitorowany i obserwowany przez pielęgniarkę. Łóżko dla pacjenta po operacji powinno być typowo ortopedyczne (twardy materac, uchwyty z regulacją wysokości barierki), co zwiększa bezpieczeństwo pacjenta. W okresie pooperacyjnym pielęgniarka musi zwrócić uwagę na możliwość wystąpienia problemów pielęgniarskich po zabiegu operacyjnym, m.in.: bólu, krwawień, powikłań zakrzepowo-zatorowych (Tabela 2).

W opiece nad chorym ważne jest kontrolowanie jego świadomości. Do oceny świadomości chorego najczęściej stosuje się skalę Glasgow [20]. Jest ona obiektywnym miernikiem stanu świadomości. Istotnym elementem jest pomiar ciśnienia tętniczego krwi. Badanie należy prowadzić w ustalonych odstępach czasu (co 1-2 godziny). Pielęgniarka każdy pomiar dokumentuje w karcie kontroli indywidualnej chorego. Każdy nieprawidłowy wynik jest zgłaszany lekarzowi. Pacjenci leżący na sali pooperacyjnej są podłączeni do urządzenia mo- nitorującego, mają prowadzony stały pomiar częstości pracy serca. Kontrolę oddechu pielęgniarka prowadzi od momentu przejęcia pacjenta z bloku operacyjnego. Oddech jest mierzony podczas kontroli podstawowych parametrów życiowych. Kontrola objętości wydalanego moczu jest bardzo istotna. Pielęgniarka prowadzi kontrolę co godzinę, zapisując ilość wydalanego moczu w karcie kontrolnej, lub prowadzi dobową zbiórkę moczu. W prowadzeniu opieki nad pacjentem ocenie podlega także barwa skóry i błon śluzowych. Obserwacji podlega również temperatura ciała i kończyny operowanej. Temperaturę mierzy się dwa razy dziennie, a jej wzrost jest zgłaszany lekarzowi, gdyż może świadczyć o powikłaniach pooperacyjnych. Przy wzroście temperatury pielęgniarka podejmuje działania obniżające gorączkę. Kładzie kompresy lodowe w miejscach przebiegu dużych naczyń krwionośnych - w okolicy pach i pachwin. O utrzymującej się gorączce informuje lekarza. We wczesnym okresie pooperacyjnym prowadzi obserwację rany i opatrunku założonego na bloku operacyjnym (opatrunek przesiąknięty dużą ilością krwistej wydzieliny może świadczyć o krwotoku wewnętrznym lub zewnętrznym). Kontroluje także ilość i charakter wypływającej treści pochodzącej z drenów. Objawy zgłaszane przez chorego oraz zmiana parametrów życiowych (wzrost tętna, wzrost ciśnienia, spłycenie oddechu, ograniczenie ruchów ciała w łóżku) informują pielęgniarkę o nasileniu bólu [7]. W takim przypadku podaje leki przeciwbólowe zgodnie ze zleceniem lekarskim.

Pielęgniarka w ocenie bólu pacjenta po zabiegu operacyjnym stosuje Skalę VAS (Visual Analogue Scale) [31]. Jest to skala wizualno-analogowa, czyli graficzna skala oceny natężenia bólu za pomocą linijki o długości $10 \mathrm{~cm}$, gdzie oznaczenie 0 - oznacza brak bólu, 10 - najsilniejszy ból. W opiece nad pacjentem istotne miejsce zajmuje także troska o sferę psychiczną chorego i jego pozytywne nastawienie do przebytej operacji. Zadaniem pielęgniarki pracującej w sali POP jest uspokojenie chorego, wyjaśnienie nurtujących go obaw, udzielenie informacji na temat przebiegu rekonwalescencji. We wczesnym okresie pooperacyjnym pacjent potrzebuje dużo spokoju i ciszy, dlatego istotne jest ograniczenie wizyt na sali pooperacyjnej do czasu, aż chory poczuje się lepiej [32].

Powikłania po zabiegu protezoplastyki stawu biodrowego obejmują także: trudności z oddawaniem moczu, zakażenie skóry, złamanie kości w trakcie i po operacji, blizny, ograniczenia ruchomości stawu biodrowego oraz obluzowanie protezy. Znieczulenie pacjenta do opisywanego zabiegu skutkuje możliwością wystąpienia zapalenia płuc, zaburzeń rytmu serca oraz uszkodzenia wątroby. Jeżeli w okresie pooperacyjnym 
dojdzie u pacjenta do zapalenia płuc, rolą pielęgniarki w pielęgnowaniu chorego jest niedopuszczenie do wystąpienia dalszych powikłań oraz możliwie jak najszybsze wyleczenie choroby. Pielęgnowanie pacjenta z zapaleniem płuc to częste wietrzenie, ale nie wychłodzenie pomieszczenia, odpowiednie nawodnienie pacjenta, oklepywanie klatki piersiowej, utrzymanie w czystości ciała i bielizny chorego, odpowiednie ułożenie pacjenta - pozycja półwysoka z głową lekko odchyloną do tyłu. Zaleca się podawanie leków na zlecenie lekarskie [32].

Badania przeprowadzone w latach 1999-2004 na Oddziale Rehabilitacji Leczniczej Wojewódzkiego Szpitala Zespolonego w Białymstoku wykazały, że wśród 70 ankietowanych po endoprotezoplastyce stawu biodrowego 36 pacjentów (51\%) potrzebowało pomocy po zabiegu operacyjnym od personelu pielęgniarskiego w celu minimalizacji i likwidacji bólu, 21 badanych (30\%) oczekiwało pomocy w zmianie pozycji ciała w łóżku, a 13 osób (19\%) wsparcia psychicznego [34, 35].

Pielęgniarki w istotny sposób wpływają na powodzenie kompleksowej rehabilitacji poprzez pomoc choremu w akceptowaniu sytuacji, w jakiej się znalazł w wyniku choroby, pobudzanie do aktywności w usamodzielnianiu, zachęcanie do współdziałania w procesie pielęgnowania i usprawniania ruchowego oraz mobilizowanie do odzyskania maksymalnej samodzielności we wszystkich czynnościach życiowych. Zapobiegają wtórnej niepełnosprawności wynikającej z hipokinezji (zmniejszona aktywność ruchowa lub jej brak) poprzez prawidłowe ułożenie chorego w łóżku, pionizację, pomoc w czynnościach samoobsługi, gimnastykę oddechową, wyposażenie łóżka w uchwyty i udogodnienia. Pomoc swoją powinny jednak ograniczyć tylko do tych czynności, których pacjent sam nie jest w stanie wykonać samodzielnie, równocześnie ucząc wykonywania czynności samoobsługowych i stwarzając warunki do samodzielnego ich wykonywania przez chorego. Pielęgniarki w swojej pracy wykorzystują model opieki według Dorothy Orem, która mówi o pomocy przy czynnościach życia codziennego w deficycie samoopieki u pacjenta [32]. Główne powikłania wraz z interwencją pielęgniarską opisano w tabeli 2.
Tabela 2. Opieka pielęgniarska nad pacjentem po zabiegu alloplastyki stawu biodrowego - podstawowe czynności pielęgniarskie i interwencja pielęgniarska

Table 2. Nursing care of the patient after hip replacement surgery basic nursing operations and nursing intervention

\begin{tabular}{|c|c|}
\hline $\begin{array}{l}\text { Powikłanie/ } \\
\text { Complication }\end{array}$ & $\begin{array}{c}\text { Podstawowe czynności pielęgniarskie/ } \\
\text { Basic nursing care activities }\end{array}$ \\
\hline $\begin{array}{l}\text { Ogólne objawy/ } \\
\text { General symptoms }\end{array}$ & $\begin{array}{c}\text { - obserwacja i monitorowanie podstawowych } \\
\text { parametrów życiowych pacjenta/observation } \\
\text { and monitoring of vital signs. } \\
\text { - kontrola wyników badań/monitoring } \\
\text { test results [37] } \\
\text { - obserwacja w kierunku odleżyn/detecting possible } \\
\text { development of bedsores [37] } \\
\text { - obserwacja tętna i temperatury kończyny/observa- } \\
\text { tion of the pulse and temperature of the limb } \\
\text { - obserwacja klatki piersiowej/monitoring } \\
\text { chest activity } \\
\text { - gimnastyka oddechowa co 1h/breathing exercises } \\
\text { once an hour } \\
\text { - zachęcanie do wykonywania głębokich wdechów i } \\
\text { wydechów/encouraging taking deep breaths } \\
\text { and exhaling [32] }\end{array}$ \\
\hline $\begin{array}{l}\text { Por } \\
\text { Con }\end{array}$ & Interwencja pielęgniarska/Nursing Intervention \\
\hline Ból/Ache & $\begin{array}{l}\text { - likwidacja bólu - leki przeciwbólowe rozpisane } \\
\text { w karcie pooperacyjnej przez anestezjologa/ } \\
\text { elimination of pain - pain relievers prescribed in the } \\
\text { patient’s postoperative chart by the anesthetist } \\
\text { - zmiana pozycji ułożeniowej i stosowanie udogod- } \\
\text { nień (poduszki, kółka pod pośladki lub pięty), aby } \\
\text { nie doszło do nadmiernego ucisku kończyny/chan- } \\
\text { ging the patient's position and the use of facilities to } \\
\text { avoid exerting excessive pressure on the limbs [36]. }\end{array}$ \\
\hline Krwawienie/Bleeding & $\begin{array}{l}\text { - zapisywanie ilości i charakteru wydzieliny } \\
\text { pojawiającej się w drenie/recording the amount and } \\
\text { properties of secretion collected in the drain }\end{array}$ \\
\hline $\begin{array}{c}\text { Powikłania } \\
\text { nerwowo-naczyniowe/ } \\
\text { Vascular complications } \\
\text { of the neuromuscular } \\
\text { system }\end{array}$ & $\begin{array}{c}\text { - obserwacja zabarwienia i temperatury operowanej } \\
\text { kończyny/observation of the color and temperature } \\
\text { of the operated limb } \\
\text { - obserwacja reakcji naczyń kapilarnych palców na } \\
\text { ucisk/observation of fingers' capillaries reaction to } \\
\text { pressure changes in fingers- } \\
\text { - obserwacja w kierunku obrzęku operowanej } \\
\text { kończyny/detecting possible development } \\
\text { of the limb oedema } \\
\text { - obserwacja czucia operowanej kończyny/monito- } \\
\text { ring sensation in the limbs }\end{array}$ \\
\hline $\begin{array}{c}\text { Zwichnięcie } \\
\text { endoprotezy/ } \\
\text { Dislocation of the } \\
\text { prosthesis }\end{array}$ & $\begin{array}{c}\text { - obserwacja w kierunku zwichnięcia endoprotezy/ } \\
\text { detection of a possible dislocation of the } \\
\text { endoprothesis } \\
\text { - używanie odpowiednich udogodnień dla pacjenta, } \\
\text { aby utrzymać kończynę w korzystnym ułożeniu/use } \\
\text { of appropriate facilities for the patient to keep the } \\
\text { leg in a preferred position [38] }\end{array}$ \\
\hline $\begin{array}{l}\text { Zakrzepowe } \\
\text { zapalenie żył/ } \\
\text { Thrombophlebitis }\end{array}$ & $\begin{array}{c}\text { - bandażowanie kończyny do wysokości uda lub } \\
\text { zakładanie specjalnych uciskowych pończoch/ban- } \\
\text { daging limbs up to the height of the thigh or using } \\
\text { special compression stockings } \\
\text { - odpowiednia pielęgnacja skóry uciśniętej/proper } \\
\text { care of the compressed skin } \\
\text { - zmiana pozycji ciała i stopniowy wzrost } \\
\text { aktywności/change of the body position } \\
\text { and a gradual increase in activity } \\
\text { - nadzór nad ćwiczeniami kończyny dolnej (zginanie } \\
\text { stopy)/supervision over the exercise of the lower } \\
\text { limb (foot bending) [39] }\end{array}$ \\
\hline
\end{tabular}




$\begin{array}{cc} & \begin{array}{c}\text { - obserwacja wyglądu rany oraz charakter i ilość } \\ \text { wydzieliny z drenu/observation of the appearance of } \\ \text { the wounds and the nature and amount of discharge } \\ \text { from the drain }\end{array} \\ \begin{array}{c}\text { Infekcja rany } \\ \text { operacyjnej/ }\end{array} & \begin{array}{c}\text { - zmiana opatrunku po przemoczeniu lub odkle- } \\ \text { Infection of the } \\ \text { surgical wound }\end{array} \\ & \begin{array}{c}\text { jeniu/changing the dressing after drenching } \\ \text { or unsticking }\end{array} \\ \text { - antybiotykoterapia na zlecenie lekarza/antibiotics } \\ \text { on the doctor's prescription [38] }\end{array}$

Źródło: opracowanie własne na podstawie [32, 36-39]

Source: author's own analysis on the basis of [32, 36-39]

\section{Przyszłość opieki pielęgniarskiej}

$\mathrm{Na}$ jeden z przyszłych, ciekawych kierunków rozwoju opieki pielęgniarskiej w późnym okresie pooperacyjnym zwrócili uwagę Jason i wsp. [39]. Klinika w Hongkongu wprowadziła kontrolę pielęgniarską dla pacjentów po całkowitej wymianie stawu biodrowego. Pielęgniarki po uprzednim przeszkoleniu miały kontrolować ocenę skuteczności wszczepu endoprotezy u chorych powyżej 2 lat po zabiegu operacyjnym. Miało to na celu odciążenie lekarzy specjalistów w dziedzinie ortopedii w dodatkowej kontroli pozabiegowej pacjentów. Pielęgniarka przechodziła szkolenie z podstawowej wiedzy na temat wymiany całkowitej stawu biodrowego oraz z fizycznych i radiologicznych cech stabilności protezy, z infekcji oraz aseptycznego obluzowania. Część szkolenia dotyczyła także informacji o różnych powikłaniach. Badania zostały przeprowadzone w okresie od lipca 2012 do marca 2014. Przebadano w sumie 431 pacjentów (114 pacjentów po całkowitej wymianie stawu biodrowego i 317 pacjentów po całkowitej wymianie stawu kolanowego), a $408(94,7 \%)$ konsultacji to samodzielne i niezależnie wykonane oceny pielęgniarskie.

Można mówić o sukcesie, ponieważ konsultacje pozabiegowe wykonywane przez pielęgniarkę zostały przyjęte przez pacjentów ze 100\% wskaźnikiem satysfakcji, a czas oczekiwania na wizytę zmniejszył się z 26 minut w 2012 roku do 14 minut w 2014 roku. Pielęgniarka zajmowała się nie tylko badaniem fizykalnym w zakresie ruchu kończyną po endoprotezie stawu biodrowego, ale także edukowała pacjenta, jak żyć ze „sztucznym stawem". Przeprowadzała ankietę, która była dołączona do procesu pielęgnowania. Została upoważniona do kierowania pacjenta na fizjoterapię, terapię zajęciową, a także do wypisywania skierowań na ortezy.

W Polsce wykonywanie zawodu pielęgniarki i położnej reguluje Ustawa o Zawodach Pielęgniarki i Położnej z dnia 15 lipca 2011 r. (Dz. U. z 2011 r. Nr 174, poz. 1039). W ustawie określone są kompetencje pielęgniarki oraz wyraźnie zaznaczona samodzielność zawodowa. Ponadto zawód pielęgniarki należy do grupy zawodów o podstawowym znaczeniu dla prowadzenia procesu diagnostyki, leczenia i rehabilitacji pacjentów.
Art. 4.1 cyt. ustawy wyraźnie stanowi o udzielaniu świadczeń, które wykonuje pielęgniarka przede wszystkim poprzez:

1. rozpoznawanie warunków i potrzeb zdrowotnych pacjenta,

2. rozpoznawanie problemów pielęgnacyjnych pacjenta,

3. planowanie i sprawowanie opieki pielęgnacyjnej nad pacjentem,

4. samodzielne udzielanie w określonym zakresie świadczeń zapobiegawczych, diagnostycznych, leczniczych i rehabilitacyjnych oraz medycznych czynności ratunkowych;

5. realizację zleceń lekarskich w procesie diagnostyki, leczenia i rehabilitacji,

6. orzekanie o rodzaju i zakresie świadczeń opiekuńczo-pielęgnacyjnych;

7. edukację zdrowotną i promocję zdrowia [40].

Jak wynika z przytoczonych uregulowań prawnych, nie ma wyraźnych przeciwwskazań do oceniania zdjęcia rentgenowskiego po endoprotezoplastyce stawu biodrowego przez pielęgniarkę pracującą na oddziale ortopedii. Doświadczona pielęgniarka, tj. pielęgniarka z wyższym wykształceniem i stażem pracy powyżej 10 lat, nie jest jednak w stanie udzielić pacjentom po zabiegu operacyjnym dalszych wskazówek do życia ze sztucznym stawem, a także w czasie kontroli nie może oceniać zdjęcia rentgenowskiego sztucznego stawu pod względem osadzenia protezy i cech obluzowania. Wynika to głównie z faktu braku kształcenia pielęgniarek w tym kierunku - brak kursu kwalifikacyjnego, szkolenia specjalizacyjnego i specjalizacji.

\section{Piśmiennictwo}

1. Sierakowski $S$. Choroba zwyrodnieniowa stawów na progu XXI wieku. Nowa Med. 2002: 2:2-3.

2. Kwiatkowski K. Choroba zwyrodnieniowa stawu biodrowego. Stand Med. 2004, 12: 1277-1281.

3. Piecuch R., Targońska-Stępniak B., Majda M. Aktualne poglądy na leczenie choroby zwyrodnieniowe stawów. Lekarz. 2008; 6:81-88.

4. Olszewski R., Wiśniewski J., Adamus J. Kwalifikacja pacjentów z chorobami serca do niekardiologicznych zabiegów chirurgicznych. Nowa Klin Vol. 9, No 11-12, 1175-1180.

5. Wytyczne ESC/ESA dotyczące operacji niekardiochirurgicznych - ocena ryzyka sercowo-naczyniowego i postępowanie w 2014 roku. Kardiol Pol 2014; 72, 10: 857-918.

6. Bednarkiewicz Z. Ocena ryzyka u chorych ze schorzeniami układu krążenia poddawanych niekardiologicznym zabiegom chirurgicznym. Nowa Klin Nr 11 (1/2): 2004; 91-95.

7. Fleisher L.A, Eagle K.A. Lowering cardiac rik In noncardiac surgery. N. Engl. J.Med. 2001; 345:1677-1682.

8. Zawadzka M., Kącka A., Byśko E., Chory kardiologiczny poddany operacji pozasercowej. Stanowisko lekarza konsultanta. Terapia. Nr 4 z 2 (192): 2007; 114-129. 
9. Mebazaa A, Pitsis AA, Rudiger A et al. Clinical review: practical recommendations on the management of perioperative heart failure in cardiac surgery. Crit Care, 2010; 14: 201.

10. Gonzalez R, Morales E, Segura J et al. Long-term renal survival in malignant hypertension. Nephrol Dial Transplant, 2010; 25: 3266-3272.

11. Poldermans D, Bax JJ, Boersma E et al. Guidelines for preoperative cardiac risk assessment and perioperative cardiac management in noncardiac surgery: the Task Force for Preoperative Cardiac Risk Assessment and Perioperative Cardiac Management in Non-cardiac Surgery of the European Society of Cardiology (ESC) and European Society of Anaesthesiology (ESA). Eur Heart J, 2009; 30: 2769-2812.

12. Calleja AM, Dommaraju S, Gaddam R et al. Cardiac risk in patients aged .75 years with asymptomatic, severe aortic stenosis undergoing noncardiac surgery. Am J Cardiol, 2010; 105: 1159-1163.

13. Bradley D, Creswell LL, Hogue CW Jr et al. Pharmacologic prophylaxis: American College of Chest Physicians guidelines for the prevention and management of postoperative atrial fibrillation after cardiac surgery. Chest, 2005; 128 : 39S-47S.

14. Pannell LM, Reyes EM, Underwood SR. Cardiac risk assessment before non-cardiac surgery. Eur Heart $\mathrm{J}$ Cardiovasc Imaging, 2013;14: 316-322.

15. Hammill BG, Curtis LH, Bennett-Guerrero E et al. Impact of heart failure on patients undergoing major noncardiac surgery. Anesthesiology 2008; 108: 559-567.

16. Dziekańska M, Latosiewicz R, Kulikowska A. Pielęgnowanie pacjenta po endoprotezoplastyce stawu biodrowego. Hygeia Public Health: 48 (3), 2013; 355-359.

17. Gaździk T.S. Ortopedia i traumatologia. PZWL: 2005; 328329, 332.

18. Malinowska K., Dega W. Rehabilitacja medyczna. Warszawa: PZWL; 1998.

19. Konieczny P, Piechowicz J, Kotela I. Standard opieki pielęgniarskiej $u$ chorych po endoprotezoplastyce stawu biodrowego. Przegląd Lekarski: 67/5: 2010; 389-397.

20. Walewska $E$ (red): Podstawy pielęgniarstwa chirurgicznego. Warszawa: PZWL; 2007.140-144.

21. Schier J.F. Kompendium pielęgniarstwa, PZWL: 1995. 463-465.

22. Bozic KJ, Kurtz SM, Lau E, Ong K, Vail TP, Berry DJ. The epidemiology of revision total hip arthroplasty in the United States. J Bone Joint Surg Am. 2009;91(1):128-33.

23. Garvin KL, Konigsberg BS. Infection following total knee arthroplasty: prevention and management. Instr Course Lect. 2012;61:411-9.

24. Bozic KJ, Lau E, Kurtz S, Ong K, Berry DJ. Patient- related risk factors for postoperative mortality and periprosthetic joint infection in medicare patients undergoing TKA. Clin Orthop Relat Res. 2012; 470(1):130-7.

25. Alisina Shahi, MD; Javad Parvizi MD, FRCS. Arch Bone Jt Surg. 2015;3(2):72-81.
26. Heck M, Fresenius M: Anästhesie bei geriatrischen Patienten; Repetytorium Anästhesiologie; wyd. V, 2007; 331-332.

27. Campbell JT, Baxter, Holte, BJ: Anesthesia 2002; 89: 622.

28. Larsen R: Anestezjologia; Wrocław: Urban \& Partner; 2003.

29. Royall DM, Dodds C: Znieczulenie do operacji urologicznych u chorych w wieku podeszłym; tłum. I. Trojanowska; Prz Now Anest 1994; 3, 2: 72-76.

30. Modesti PA, et al. Intern. Emerg Med 2006: 1, 177.

31. Kocot-Kępska M, Szułdrzyński K. Skale oceny bólu. http:// www.mp.pl/bol/wytyczne/show.html?id=91404; (data dostępu: 24.04.2016).

32. Pączek L, Foroncewicz B, Mucha K. Choroby wewnętrzne. Podręcznik dla studentów pielęgniarstwa i położnictwa. Warszawa: PZWL; 2006. 222-234.

33. Górajek-Jóźwik J. Filozofia i teorie pielegniarstwa. Warszawa: Wyd. Czelej;. 2008. 299-310.

34. Strode I., Logina I. Assessment of Postoperative pain in Nursing. Acta Chir Latviensis, 2009;9:77-80.

35. Sjoling M, Nordahl G, Olofsson N, Asplund K. The impact of preoperative information on state anxity, postoperative pain and satisfaction with pain management. Patient Educ Couns 2003;51: 169-176.

36. Twycross A. Educating nurses about pain management: the way forward. J Clin Nurs 2002; 11: 705-714.

37. Kózka M. Wybrane standardy opieki pielęgniarskiej. Kraków: UJ; 1997.

38. Białecki J, Brychcy A, Marczyński W. Preparation of patients for hip or knee replacement surgery as an important element in preventing periprosthetic joint infection. Pediatr Med Rodz 2015, 11 (2), p. 205-209.

39. Jason CH Fan * Carmen KM Lo, Carson KB Kwok, KY Fung: Nurse-led orthopaedic clinic in total joint replacement Introduction, Hong Kong Med J. 2014; 20:511-8.

40. Ustawa z dnia 15 lipca 2011 r o zawodach pielegniarki i położnej http://isap.sejm.gov.pl/DetailsServlet?id=WDU20111741039 (data dostępu: 29.08.2016).

Artykuł przyjęty do redakcji: 02.09.2016

Artykuł przyjęty do publikacji: 12.10.2016

Źródło finansowania: Praca nie jest finansowana z żadnego źródła. Konflikt interesów: Autorzy deklarują brak konfliktu interesów.

\section{Adres do korespondencji:}

Katarzyna Majka

ul. Szaserów 128

04-141 Warszawa

tel.: 694508723

e-mail: Katarzyna.majka@wum.edu.pl

Klinika Traumatologii i Ortopedii

Wojskowy Instytut Medyczny, Warszawa 